\title{
NOVÉ NÁLEZY KADLUBŮ A PŘECHODNÉHO POZITIVU URČENÉHO K VÝROBĚ KACHLŮ Z LOŠTIC (OKRES ŠUMPERK)
}

\section{LUKÁŠ HLUBEK}

\begin{abstract}
Abstrakt: Článek se věnuje novým nálezům přechodného pozitivu a několika fragmentů kadlubů určených $k$ výrobě kamnářské keramiky, které pochází z okoli domu čp. 103 v Lošticích. Podle sdělení nálezce byly vyzvednuty z jámy spolu s keramikou z konce 15. až první poloviny 16. století, přičemž některé kusy hrnčiny lze označit za defektni výrobky. Je pravděpodobné, že někde v blizkosti domu existovala na konci 15. až v prvni polovině 16. století hrnčiřská dillna. Ta kromě běžné stolni a kuchyňské keramiky produkovala také komorové kachle.
\end{abstract}

Klíčová slova: Loštice - středověk - novověk - kadluby - výroba kamnářské keramiky.

New finds of moulds and a temporary positive mould for the production of tiles from Loštice (Šumperk district)

\begin{abstract}
This article is devoted to the new finds of a temporary positive mould and several fragments of moulds for the production of stove ceramic, from the vicinity of house no. 103 in Loštice. According to the finder, they were unearthed, together with pottery from the late 15th century - first half of the 16th century. Some of the pottery can be considered workshop rejects. In all probability, there existed a pottery workshop near the house between the late 15th century and the first half of the 16th century. Apart from ordinary tableware and kitchenware it also produced chamber tiles.
\end{abstract}

Key words: Loštice - Middle Ages - modern age-moulds - production of stove ceramic.

\section{Úvod}

Loštice (obr. 1) leží v západní části Mohelnické brázdy. Rozkládají se na obou březích řeky Třebůvky v průměrné nadmořské výšce $258 \mathrm{~m}$. Nejstarší doklady osídlení v intravilánu i blízkém okolí města evidujeme od doby kamenné až po raný středověk (např. Goš 1978, 134-136; 2007, 7-9; Faltýnek 2015, 21-43). Během první čtvrtiny 13. století zde nechal vystavět Petr z Loštic pozdně románský kostel sv. Prokopa, v jehož blízkosti měl nejspíš svou vlastní rezidenci (Šlézar-Faltýnek 2019, 178-191). Roku 1353 byly Loštice v písemných pramenech poprvé uvedeny jako městečko. Během 14. století došlo k postupnému připojení Loštic k bouzovskému panství, ke kterému náležely až do roku 1585, kdy je za 12000 zlatých od Jindřicha staršího Podstatského z Prusinovic odkoupilo královské město Uničov (Kuča 1998, 640-644; Jandíková 1998, 10-12; Goš 2007, 21).

V archeologické literatuře jsou Loštice známé především jako středověké a raně novověké hrnčířské centrum. Počátky výroby místní specifické keramiky kladl V. Goš do 13. století (např. Goš-Novák 1976; Goš 2007, 14-16). Zcela nepochybně můžeme za nejvýznamnější etapu hrnčířského řemesla považovat průběh 15. až první polovinu 16. století, kdy zde byly vyráběny proslulé loštické poháry (nap̌r. Goš 2007, 98-100; 2012, 12). $\mathrm{V}$ písemných pramenech se s loštickými hrnčíŕi setkáváme až v letech 1481 a 1484. Tehdy jim bylo vyměřeno mýtné plynoucí do panské poklady, a to 5 grošů na Úsově, 2 denáry

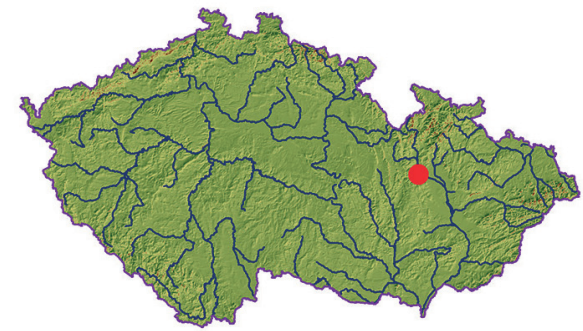

Obr. 1. Loštice. Studovaná lokalita na mapě České republiky. Vytvořil T. Liczka.

Abb. 1. Loštice. Untersuchte Fundstelle auf einer Karte der Tschechischen Republik. Erstellt von T. Liczka. 
v Mladči a 1 haléř z vozu hrnců vezených do těchto míst na trh (Šefčík 1984, 274). Zhruba v polovině 16. století poklesl na trhu zájem o loštické poháry a jejich výroba postupně upadala. Je pravděpodobné, že typické loštické zboží z trhu vytlačily kvalitnější výrobky novokřtěnských hrnčířủ (Goš 1998, 61; 2007, 99, 104).

Hrnčířské řemeslo bylo v Lošticích provozováno až do první poloviny 20. století. Se zdejším hrnčířským cechem se setkáváme poprvé v listině vydané 24. dubna 1545. Text dokumentu zmiňuje cechmistry a mistry řemesla hrnčířského z městečka Loštic a blízké vsi Pavlova (Houdek 1891, 62). Nejstarší dochovaná cechovní pečet' hrnčírư z Loštic je datována rokem 1555. Z písemných pramenů víme, že v roce 1755 pracovalo ve městě 18 hrnčírůu, v roce 1838 dokonce 24 . Jejich počet začal v průběhu 19. století výrazně klesat. V roce 1929 už byly uváděny pouze dvě hrnčířské rodiny a tři kamnáři. O jedenáct let později evidujeme z Loštic již jen dva kamnáře (Šefčík 1984, 272-278; Goš 1998, 61; 2007, 97).

Na základě analýzy písemných pramenů i publikovaných výsledků archeologických výzkumů v různých částech Loštic máme výrobu jak standardní, tak věhlasné loštické keramiky za jednoznačně prokázanou (srov. Goš-Novák 1976, 400-403; Drobná 1957, 102; Lang 1961, 57-59; Nekuda-Reichertová 1968, 150; Goš 1983, 197-207; 2007, 96-98; 2012, 11-12; Bláha-Goš 1999, 592-593; Zatloukal 2000, 65-66; Hlubek 2018, 252-253; 2019, 282; Št’astný-Dudek-Goš 2018, 96-99). Naproti tomu pro zhotovování kamnářské keramiky zatím máme pouze nepřímé indicie. Loštický badatel A. Lang uvedl, že na střepištích byly nacházeny také neupotřebené kachle. Za průkaznější stopy jejich místní produkce můžeme označit dvě formy určené ke zhotovování kachlů z areálu města (Lang 1957, 29; Vitanovský 2008, 158, 160, kat. č. 520, 520a; Tymonová 2014, 160; Hlubek 2015, 221-226, obr. 2-4).

\section{Kolekce nálezů z areálu domu čp. 103 v Lošticích}

V roce 2018 se autor článku seznámil s majitelem domu čp. 103 v Lošticích (obr. 2). Ten mu umožnil prohlédnout si vyzvednuté archeologické nálezy, které v drtivé většině případů získal jeho otec v prostoru zahrady (například při sázení stromů, rytí záhonů atd.). Podařilo se mu tak shromáždit poměrně rozsáhlou kolekci archeologického materiálu, který lze zařadit do pravěku (kultura s lineární keramikou, lužická kultura), středověku (zejména 14.-15. století) a raného novověku (16.-19. století). Celou sbírku tvoří především zlomky keramických nádob různých velikostí, méně již fragmenty komorových kachlů a kovové artefakty. Výběr nálezů předal majitel domu do sbírky Vlastivědného muzea v Olomouci (dále jen VMO). Tuto darovanou kolekci doplňují dva defektní kusy spečené loštické hrnčiny

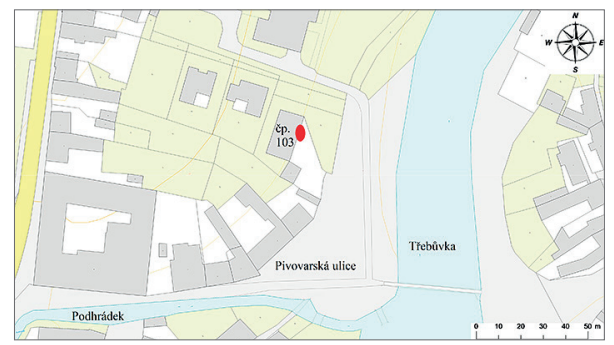

Obr. 2. Loštice. Přibližná poloha jámy obsahující kadluby a přechodný pozitiv. Zdroj www.cuzk.cz, vytvořil L. Hlubek.

Abb. 2. Loštice. Ungefähre Lage der die Gießformen und die provisorische Positivform enthaltenden Grube. Quelle www. cuzk.cz, erstellt von L. Hlubek. (k tomu Hlubek 2019, 282, obr. 68, 69).

V dalším textu se zaměříme na fragment přechodného pozitivu a zlomky kadlubů určených $\mathrm{k}$ výrobě kachlů, které byly věnovány do VMO v roce 2019. ${ }^{2}$ Podle sdělení majitele domu všechny tyto nálezy pocházejí z výkopu při východní stěně domu čp. 103. V rámci výkopu nálezce identifikoval blíže neurčený objekt s hutnou černou výplní, která obsahovala značné množství keramiky z konce 15 . až první poloviny 16. století (obr. 3), zlomky loštické hrnčiny (obr. 3:1, 5), včetně několika fragmentů kadlubů a torza přechodného

1 Nálezy zapsány do sbírek VMO pod přír. č. 7/2018.

2 Nové nálezy kadlubů a pozitivní formy prezentoval autor př́spěvku na semináři Kachlice krásných slohov v Trebišově dne 10 . ř́jna 2018. 

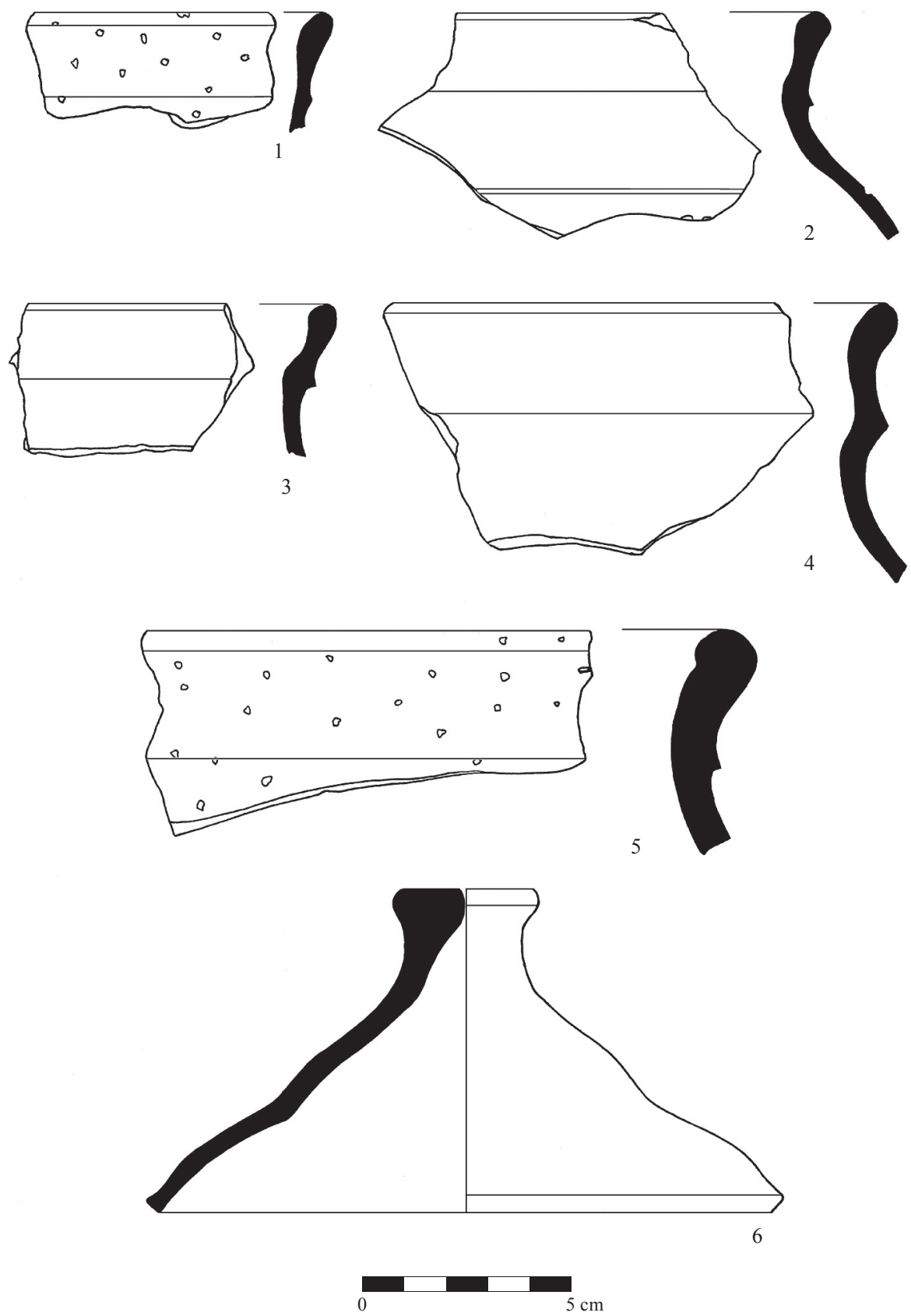

Obr. 3. Loštice. Výběr keramiky z jámy u východní zdi domu čp. 103. Kresba L. Hlubek.

Abb. 3. Loštice. Auswahl der Keramik aus der Grube an der Ostwand von Haus Nr. 103. Zeichnung L. Hlubek. 
pozitivu (obr. 4, 5)3 (Hlubek v tisku). Některé kusy stolní a kuchyňské keramiky můžeme označit za defektní výrobky (zkroucené či jinak deformované exempláře). Avšak přesnější interpretace této jámy není možná.

\section{Popis kadlubů a přechodného pozitivu}

Kadlub č. 1 -jde o spodní polovinu formy na výrobu kachlů obdélného formátu. Forma je složena ze čtyř různě velkých fragmentů. Na okrajích se nachází negativ užší hranolové lišty. Na ploše kadlubu se nachází negativ částečně dochované aureoly, v níž je umístěn blíže neurčený motiv. Z něj je dobře rozpoznatelný pouze rostlinný úponek na levé straně, u spodního okraje registrujeme plášt’ či zřasené šaty a z nich vystupující chodidlo. Snad by mohlo jít o motiv Panny Marie ve
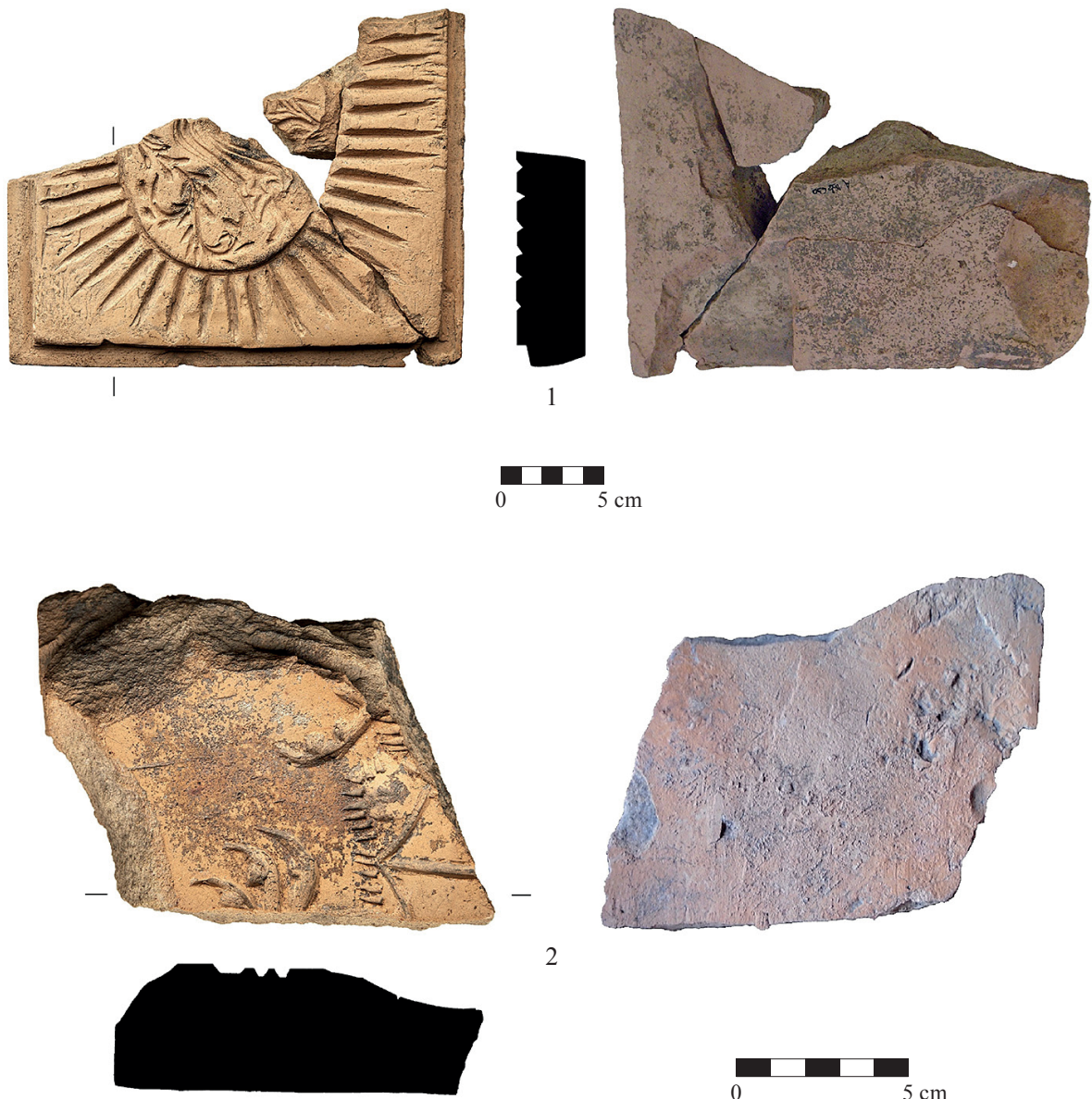

2

Obr. 4. Loštice. Kadlub č. 1 a 2. Foto P. Rozsíval, kresba L. Hlubek.

Abb. 4. Loštice. Gießform Nr. 1 und 2. Foto P. Rozsíval, Zeichnung L. Hlubek.

3 Kolekce nálezů uložena ve VMO pod prrír. č. 10/2019. Přechodný pozitiv zůstává i nadále v soukromé sbírce. 
slunci (viz níže). ${ }^{4}$ Celá zadní plocha nese stopy po zahlazení povrchu. Kadlub je vyroben z jemné hlíny, která má po oxidačním výpalu okrovou až cihlovou barvu a tvrdý výpal. Na hranách nalézáme tzv. sendvičový efekt. Keramická hmota obsahuje zejména písek a ojedinělá zrnka slídy. Rozměry: max. délka 180 mm, šířka 228 mm, celková tloušt'ka kadlubu 30-33 mm (obr. 4:1).

Kadlub č. 2 - torzo formy na výrobu kachlů má na čelní ploše negativ blíže neurčeného motivu. Rozpoznatelné jsou snad spáry (?) u spodního okraje a část zvířecího trupu (?) doplněného řadou krátkých rýžek. Zadní strana má oproti kadlubu č. 1 pečlivěji zahlazený povrch. Kadlub je vyroben z jemné hlíny, která má po oxidačním výpalu okrovou až cihlovou barvu a tvrdý zvonivý výpal. Na hranách nalézáme tzv. sendvičový efekt. Hmota obsahuje písčitou př́iměs. Rozměry: max. délka $125 \mathrm{~mm}$, max. šířka $95 \mathrm{~mm}$, celková tloušt'ka formy $37 \mathrm{~mm}$ (obr. 4:2).

Zlomky dalšich kadlubi̊ - pocházejí z blíže neurčených forem (obr. 5:1-4). Celkovým provedením, barvou i strukturou keramického těsta se podobají výše popsaným kadlubům (obr. 4:1, 2). Ve všech prŕípadech jde jen o části svrchních stran s negativem motivů, aniž bychom znali celkovou sílu formy. Na ploše lícní strany rozpoznáváme část pláště či šatů (obr. 5:1), neúplnou svatozář (obr. 5:2), zlomek aureoly s hranolovou okrajovou lištou (obr. 5:4) a na posledním fragmentu je negativ hranolové okrajové lišty (obr. 5:3). Maximální měřitelné rozměry u všech zlomků činí: délka $68 \mathrm{~mm}$, šířka $33 \mathrm{~mm}$, tloušt'ka $22 \mathrm{~mm}$. Pravděpodobně lze u dvou fragmentů forem s aureolou a hranolovou okrajovou lištou (obr. 5:3,4) uvažovat o tom, že tyto zlomky nejspíše pocházejí z kadlubu č. 1 (obr. 4:1), jistotu ale nemáme.

Přechodný pozitiv - se dochoval přibližně z jedné čtvrtiny. Jde o levý dolní roh s ledabyle vymodelovanou okrajovou lištou ve tvaru užšího hranolu. Na ploše výrobku je část vlevo natočeného trupu zvířete (nejspíše lva) s plasticky znázorněnou hřívou postaveného na zadních nohou a přední tlapou směřující k levému spodnímu rohu (obr. 5:5). Za zmínku stojí, že tělo zvířete vymezuje řada krátkých rýžek, přičemž totožný výzdobný prvek evidujeme na kadlubu č. 2 (srov. obr. 4:2). Celá zadní plocha nese stopy po zahlazení povrchu a po okrajích nezaznamenáváme žádné stopy pro připojení komory. Přechodný pozitiv je vyroben z jemné písčité hlíny, která má po oxidačním výpalu okrovou až cihlovou barvu a tvrdý výpal. Rozměry: max. délka $178 \mathrm{~mm}$, max. šíŕka 147 mm, tloušt'ka 17-23 mm (obr. 5:5). ${ }^{5}$

\section{Datování kadlubů a přechodného pozitivu}

Pokusíme-li se datovat výše popsané kadluby a přechodný pozitiv, pak je to možné na základě rozboru motivů na vybraných formách a ostatních nálezů pocházejících z jámy. Celkové množství získané stolní a kuchyňské keramiky lze odhadnout na několik stovek kusů. Z objektu u východní zdi domu čp. 103 máme dnes $\mathrm{k}$ dispozici pouze malou část nálezů (úhrnem $8 \mathrm{ks}$ ) z celého vyzvednutého souboru. Keramika je vypálena do oranžovobéžové barvy a ve dvou případech evidujeme šedou barvu na povrchu (obr. 3:2). Síla hrnčiny osciluje od 4 do $8 \mathrm{~mm}$. Z ostřiva je makroskopicky pozorovatelný především písek a ojedinělé šupinky slídy. Celkem máme $\mathrm{k}$ dispozici osm zlomků keramiky, z toho jedno větší torzo zvonovité poklice s knoflíkovitým držadlem (obr. 3:6), tři okraje hrnců formovaných do tvaru okruží (obr. 3:2-4), po jednom okraji z loštického hrnce (obr. 3:5) a poháru bez oušek (obr. 3:1); dále zlomek stěny hrnce či džbánu s prožlabeným páskovým uchem a část nezdobené výdutě se šedou barvou na vnitřní straně a na vnější straně okrovou.

Podle okrajové profilace hrnců, výskytu loštické hrnčiny, převládající oranžovobéžové barvy, písčité příměsi v keramickém těstě a některých už vyloženě tenkostěnných fragmentů lze celou kolekci zařadit spíše do závěru 15. až první poloviny 16. století. Jde o tzv. přechodné období mezi pozdně středověkou a nastupující raně novověkou produkcí keramiky (srov. Pajer 1983, 5-9, 14-17, 21-23). Středomoravské keramice z tohoto časového intervalu zatím nebyla

4 Děkuji touto cestou za radu PhDr. Ireně Loskotové, Ph.D., z Ústavu archeologie a muzeologie Filozofické fakulty Masarykovy univerzity, Brno. 5 Nález z Loštic rozšiřuje počet přechodných pozitivů z prostoru střední Moravy. Dosud známe tyto výrobky z areálu měst Uničova, Šternberka a Prostějova (srov. Menoušková-Vitanovský 2011, 16-26; Tymonová 2014, 160). 

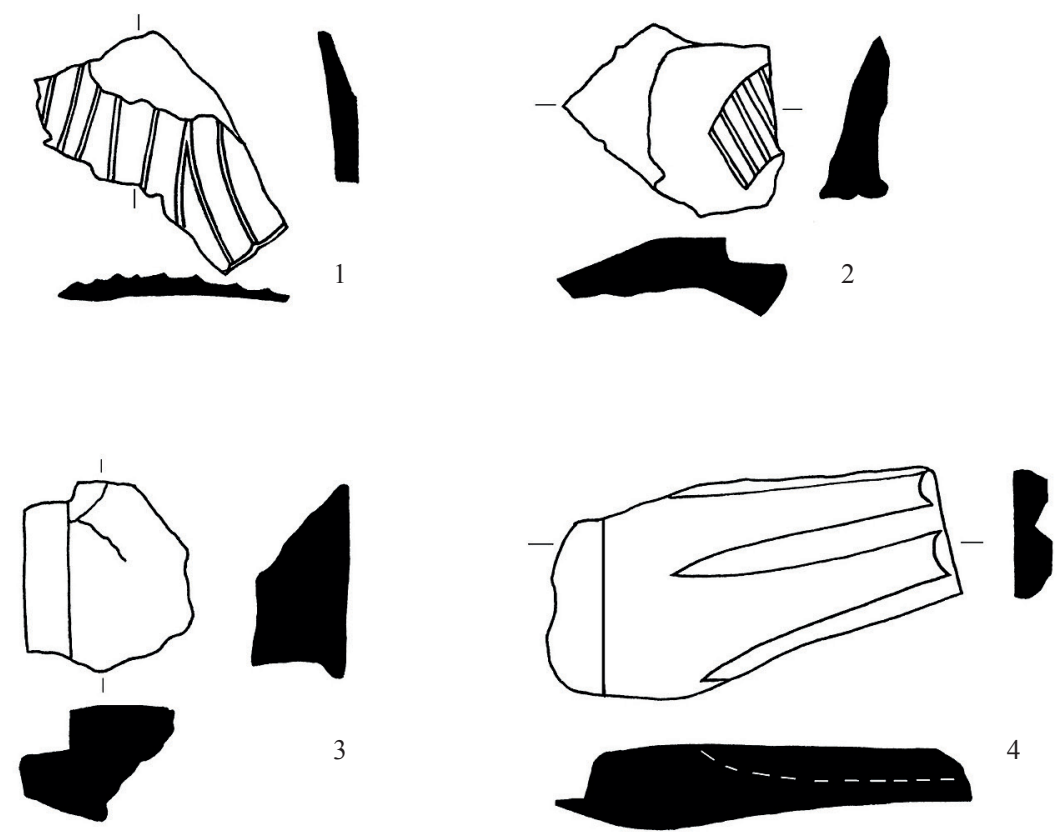

3
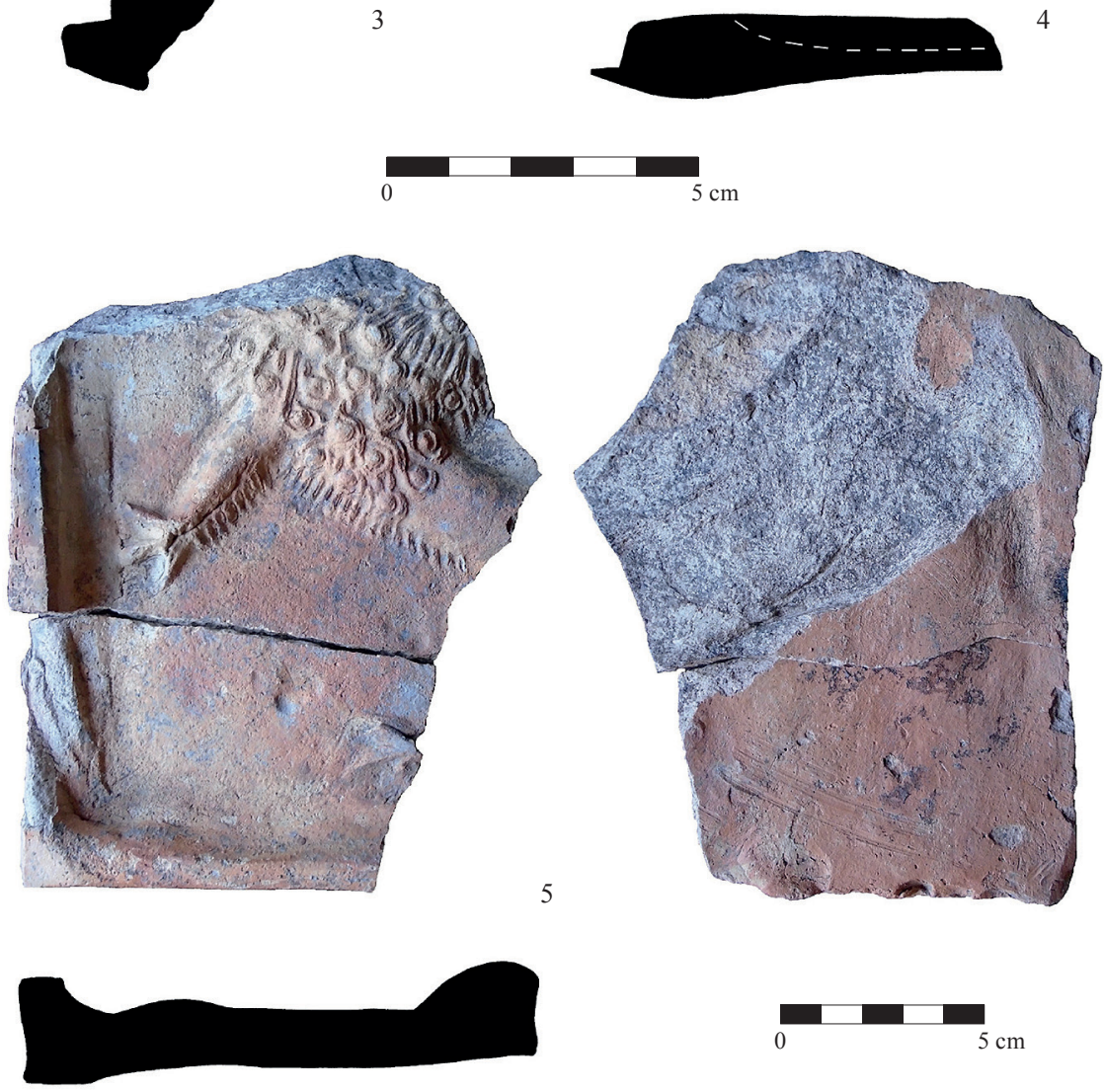

Obr. 5. Loštice. Zlomky kadlubů a přechodný pozitiv. Foto P. Rozsíval, L. Hlubek, kresba L. Hlubek.

Abb. 5. Loštice. Fragmente der Gießformen und provisorische Positivform. Foto P. Rozsíval, L. Hlubek, Zeichnung L. Hlubek. 
věnována důkladnější pozornost (srov. Bláha-Sedláčková 1998, 15-16; Goš 2007, 99). Podobnou kolekci nálezů známe např́íklad z města Olomouce z odpadní jímky na Dolním náměstí čo. 7 (Prečanová 1999, 24-31, 40-41, obr. 20:1, 3, 5, 7-9; 23:2-5; 24), nebo lze uvést velmi stručně popsané jednotlivé kusy z prostoru Žerotínova náměstí, olomoucké školy u kostela sv. Mořice či z intravilánu Chořelic (Bláha 1983, 308-312; Bláha-Sedláčková 1998, 15, kat. č. 13.1, 19.1; Bláha 1999, 588; 1999a, 616-626, zvláště kat. č. 611-619; 2005, 53-54, obr. na s. 58; Faltýnek 2012, 85-86, tab. 2:43). ${ }^{6}$

Nyní obrátíme pozornost $\mathrm{k}$ samotným kadlubům a přechodnému pozitivu. Bohužel se nepodařilo dohledat žádnou přímou analogii mezi kamnářskou keramikou na území Moravy. Nicméně podle negativů motivů na svrchní straně, celkového provedení nebo okrajových lišt se zdá pravděpodobnější jejich zařazení do druhé poloviny 15 . až prvních desetiletí 16. století. Pro dataci je nejvhodnější kadlub č. 1 (obr. 4:1), z něhož se dochovala zhruba polovina. Pokud se zaměříme na aureolu, nacházíme pro ni paralely častěji na komorových kachlích datovaných do doby kolem roku 1500. Jde o nálezy kamnářských výrobků čtvercového či obdélného formátu s motivem Panny Marie (Madony) v aureole nebo ve slunci, které evidujeme mezi nálezy z hradů Lipnice, Cvilína a z měst Kutné Hory nebo Brna (srov. Pavlík-Vitanovský 2004, 38, 201-202, 330, kat. č. 138-140; Loskotová 2011, 20, 153, tab. 9). Velkou míru shody s loštickým kadlubem vykazují dva fragmenty čelních vyhřívacích stěn kachlů $\mathrm{z}$ náměstí Svobody a Kapucínského náměstí v Brně (obr. 6:1). Formu i oba brněnské zlomky spojuje obdélný formát, okrajová lišta ve tvaru úzkého hranolu a zejména podobně provedený rozvětvený rostlinný úponek vedle postavy $\mathrm{v}$ aureole (srov. Loskotová 2011, tab. 9). Oba brněnské exempláře jsou zařazeny do závěru 15 . století, což umožňuje datovat kadlub č. 1 z Loštic totožně.

Na svrchní straně přechodného pozitivu je dochována část trupu zvířete $s$ hřívou. Právě plasticky bohatě znázorněná hřiva a řada drobných rýžek podél trupu a nohou zviřrete nejvíce připomínají některé reliéfy lvů na čelních vyhřívacích stěnách kachlů (srov. Pavlík-Vitanovský 2004, 129, 394, kat. č. 827-829; Pavlík 2017, 63, 456-457, kat. č. $1037,1040,1043,1045,1046,1050,1054)$,
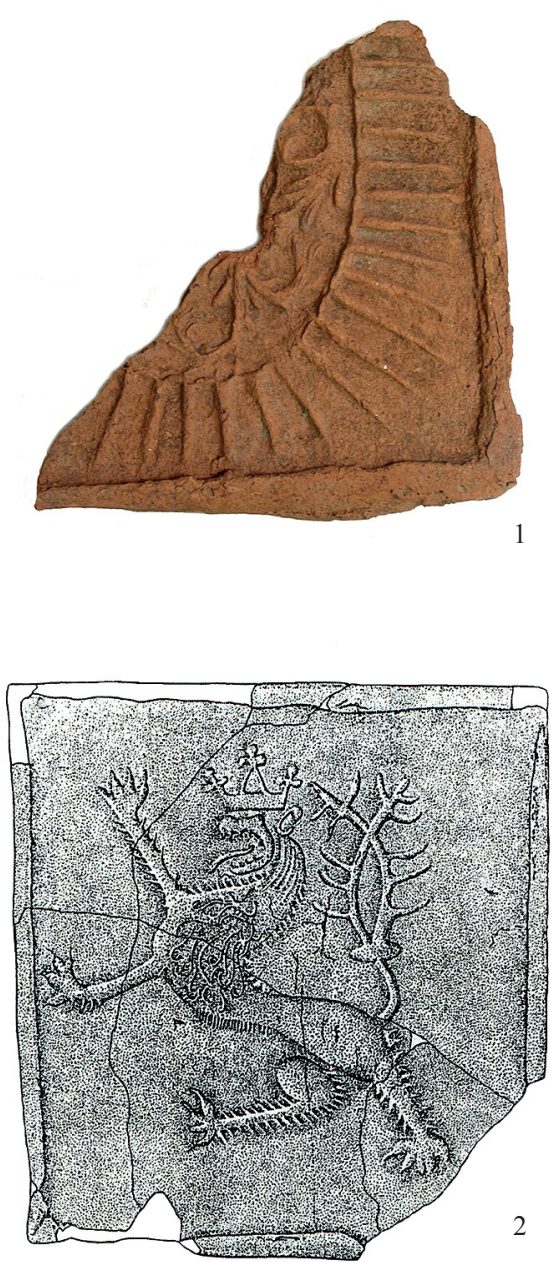

Obr. 6. Nálezy kachlů s motivem Panny Marie ve slunci z Brna (1) a motivem korunovaného lva z Mohelnice (2). 1 - Foto I. Loskotová, 2 - podle Bláha 1999b.

Abb. 6. Funde von Kacheln mit dem Motiv Maria in der Sonne aus Brünn (1) und dem Motiv eines gekrönten Löwen aus Mohelnice (2). 1 - Foto I. Loskotová, 2 - nach Bláha 1999b.

6 Pro úplnost lze uvést ještě podobně charakterizovanou kolekci stolní a kuchyňské keramiky z mnohem vzdálenějšího Lipníku nad Bečvou (srov. Drechsler-Pavlík-Vitanovský 2008, 19, 23, např. tab. VII:1, 3-6). 
zvláště pak korunovaného lva na kachli čtvercového formátu z biskupského domu v Mohelnici (srov. Bláha 1999b, 601, kat. č. 549; Hazlbauer-Heidenrich-Lamr 2001, 388, 392, obr. 3:2). Tento exemplář (obr. 6:2) je zařazen do druhé poloviny 15. století. I když postavení nohou zvířat na kachli z Mohelnice a přechodném pozitivu z Loštic není totožné (srov. Hazlbauer-HeidenrichLamr 2001, 388, 392, obr. 3:2), je možné na základě podobného znázornění hřívy uvažovat o tom, že tyto dva reliéfy jsou si poměrně blízké.? Pokud je tato premisa správná, pak můžeme připustit datování přechodného pozitivu z Loštic do průběhu druhé poloviny až konce 15. století.

Výše popsaná kolekce fragmentů forem a přechodného pozitivu pocházející z jedné jámy představuje sama o sobě výjimečný soubor, nebot' z celé České republiky evidujeme okolo 100 kusů těchto artefaktů (srov. Tymonová 2014, 160). Je třeba litovat toho, že k získání zde popsaných exemplářů nedošlo v průběhu archeologického výzkumu, což snižuje jejich výpovědní hodnotu, a zároveň dochází $\mathrm{k}$ jejich zveřejnění až s velkým časovým odstupem od vyzvednutí. I přesto samotná koncentrace několika zlomků kadlubů a přechodného pozitivu v jedné jámě naznačují, že někde v okolí domu čp. 103 mohla existovat hrnčířská dílna, která produkovala také kamnářské zboží (viz níže).

Je možné předpokládat, že všechny exempláře sloužily $\mathrm{k}$ výrobě komorových kachlů. Soudím, že v případě referovaných forem (obr. 4; 5:1-4) jde o finální negativy sloužící k výrobě základních kachlů. Nalezené zlomky matric i přechodný pozitiv spojuje podobné celkové provedení. Zaráží však, že na zadní straně větších kusů nenacházíme zesílenou lištu nebo středovou opěrku, která by zabraňovala zlomení formy během výroby (srov. Vitanovský-Menoušková 2010, 686, obr. 9; Menoušková-Vitanovský 2011, 17-18). Zadní strany loštických kadlubů jsou jen hrubě zahlazeny. Za vzácný nález v celé kolekci můžeme označit přechodný pozitiv. U nás jde o jeden z mála známých kusů vůbec (srov. Vitanovský-Žegklitz 2011; Menoušková-Vitanovský 2011; Tymonová 2014, 160-161). Přechodný pozitiv představuje výrobní mezičlánek mezi prvotním negativem (modelem) a vlastním kadlubem (např. Erneé-Vitanovský 2003, 553-557; Vitanovský 2008, 158).

\section{Existovala kamnářská dílna v Lošticích v okolí domu čp. 103?}

Na základě různých zmínek v literatuře je zřejmé, že v Lošticích zhotovovali kachle zdejší hrnčíři nejspíše od sklonku vrcholného středověku až do první poloviny 20. století. Podle A. Langa byly kamnářské výrobky nacházeny jak na střepištích, tak i jednotlivě. Často mělo jít o nepoužité výrobky (Lang 1957, 29-30). Z areálu Loštic jsme dosud evidovali dvě formy určené k výrobě kamnářské keramiky, které představují nepřímé doklady produkce komorových kachlů. První kadlub sloužil výrobě římsového kachle $\mathrm{s}$ heraldickým motivem anděla štítonoše držícího erb se zkřriženými ostrvemi, na jeho ploše se nachází letopočet $1675 .{ }^{8} \mathrm{Na}$ druhé formě je částečně dochován negativ rozety s vinnými hrozny po stranách. Bohužel k oběma exemplářum schází bližší nálezové okolnosti (Hlubek 2015, 224-226, zde i další literatura). Z dosud publikovaných výsledků archeologických výzkumů stále nevíme, kam v městském areálu lokalizovat dílnu, či dílny vyrábějící kamnářské zboží (např. Goš 2007, 73).

Výše popsané formy nalezené u domu čp. 103 (obr. 7:1) pochází z prostoru mezi Hradskou ulicí a řekou Třebůvkou. Zde se také původně nacházela zahrada stavitele K. Hladiše, který roku 1874 objevil a jako první popsal nález loštických pohárů, včetně několika komorových kachlů (Hladiš 1885, 184-186). V roce 1951 provedli v zahradách za domy A. Lang a H. Landsfeld sondážní výzkum a nejspíše zde odkryli část pece. Další nálezy z Hradské ulice pocházejí z roku 1958, kdy z výkopu u kulturního domu (obr. 7:2) A. Lang získal početný keramický materiál spolu s kusy

\footnotetext{
7 Určitou paralelu lze také sledovat na kachlích s motivy lvů z Loštic a hradu Bouzova, odkud známe dva podobné reliéfy na čelních vyhřívacích stěnách kamnářských výrobků, které se od sebe odlišují zejména zpracováním ocasu zvířete. Oproti nálezu z Loštic má lev na kachli z hradu Bouzova vložen do prostoru mezi ocasy tlapatý křížek (srov. Pavlík-Vitanovský 2004, 129-130, 394, kat. 835; Lansfeld 1976, nestránkováno). 8 Jde však o tzv. pirátskou kopii kachle z počátku 16. století, který známe např́iklad z blízkého hradu Bouzova (Vitanovský 2008, 158, kat. č. 520, 520a).
} 
spečenin. Snad šlo o části stěny či kupole pece (Faltýnek 2009, 269-271, obr. na s. 261-263). Záchranný archeologický výzkum v této části města proběhl v souvislosti se stavbou domu s pečovatelskou službou v roce 1980 (obr. 7:3). V. Kapl a V. Goš prozkoumali jeden objekt naplněný defektními výrobky. Tento objekt nejspíše vznikl z důvodu získávání zdejších hlín k výrobě hrnčiny a následně byl zaplněn odpadem vzniklým při výrobě keramiky spolu s rozrušenými klenbami pecí (Goš 1983, 200; Zatloukal 2000, 65-66; Goš 2007, 38). Další záchranný výzkum na Hradské ulici realizovali pracovníci olomouckého pracoviště Národního památkového ústavu na parcele č. 1524 (obr. 7:4), odkud pochází menší soubor keramiky z mladší doby hradištní a raného novověku (Dehnerová-Hejhal 2001; Dehnerová-Hejhal 2002, 270). Z pozemku domu na Pivovarské ulici čp. 7 (obr. 7:5) známe jeden kus s několika spečenými loštickými poháry k sobě (Hlubek 2018, 252, obr. 64). Všechny dosud zveřejněné výsledky výzkumů umožňují do této části města lokalizovat hrnčířské

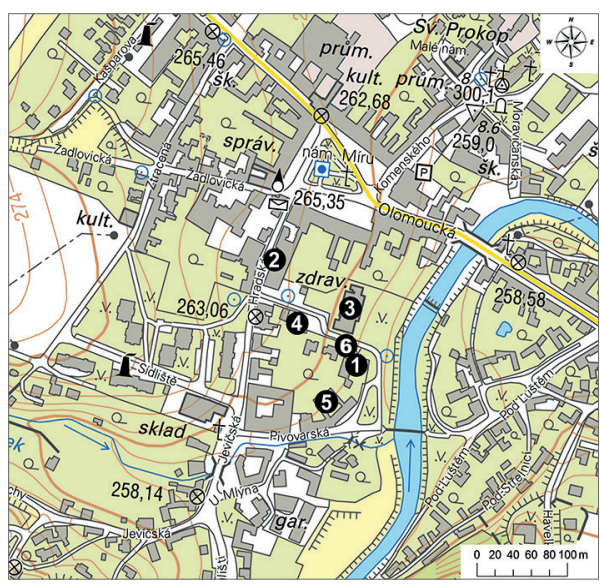

Obr. 7. Loštice. 1 - dům čp. 103; 2 - kulturní dům; 3 - dům s pečovatelskou službou, 4 - místo výzkumu na parcele č. 1524; 5 - dům Pivovarská ulice čp. 7; 6 - místo náhodně objevené pece mezi zahradou a silnicí $k$ domu $s$ pečovatelskou službou. Zdroj www. cuzk.cz, upravili P. Rozsíval a L. Hlubek.

Abb. 7. Loštice. 1 - Haus Nr. 103; 2 - Kulturhaus; 3 - Pflegediensthaus, 4 - Grabungsstelle auf Parzelle Nr. 1524; 5 - Haus Pivovarská-Straße Nr. 7; 6 - Stelle des zufällig entdeckten Ofens zwischen dem Garten und der zum Pflegediensthaus führenden Straße. Quelle www. cuzk.cz, bearbeitet von P. Rozsíval und L. Hlubek.

dílny, včetně jejich předpokládaného zázemí (srov. Goš 2007, 35-38).

Nově získané nálezy kadlubů a přechod-

ného pozitivu vyzvednuté u domu čp. 103 mohou pocházet z okolí předpokládané hrnčířské dílny. Tuto interpretaci podporují také dva zlomky spečených kusů loštické keramiky, které majitel domu předal v roce 2018 do olomouckého muzea (Hlubek 2019, obr. 69). Tento možný výklad doplnil majitel domu čp. 103, který autorovi příspěvku sdělil informaci o náhodně objevené části hrnčířské pece. Ta se nacházela v prostoru mezi jeho pozemkem a silnicí $\mathrm{k}$ domu s pečovatelskou službou (obr. 7:6). Podle jeho slov byl na profilu výkopu jasně zřetelný dutý prostor kupolovitého tvaru s dočervena propálenými stěnami. Je třeba litovat toho, že tento objekt nebyl archeologicky prozkoumán, nebot' z intravilánu Loštic registrujeme řádně prozkoumanou pouze jednu jednoprostorovou hrnčířskou pec se čtyřmi vstupními otvory na Komenského ulici (Goš 1982, 27-29; 1983, 198; Procházka 2015, 217, 222). ${ }^{9}$

I když na pozemku domu čp. 103 nebyl proveden žádný archeologický výzkum, můžeme na základě výpovědi majitele nemovitosti a získaných nálezů s vysokou mírou pravděpodobnosti soudit, že nejspíše na konci 15. až v první polovině 16. století někde v okolí domu existovala hrnčířská dílna. Ta produkovala jak běžnou, tak i loštickou keramiku. Nalezené formy a přechodný pozitiv indikují zhotovování kamnářského zboží. V současné chvíli ale nelze říci, zda nálezy získané na pozemku domu čp. 103 a náhodně objevená hrnčířská pec spolu souvisejí či nikoliv.

\section{Závěr}

Již od konce 19. století náleží Loštice k významným archeologickým lokalitám na celé Moravě. Jejich věhlasu výrazně napomohla skutečnost, že právě zde byly v průběhu 15. až první poloviny

9 V intravilánu Loštic bylo prozkoumáno pecí více (srov. Goš 2007, 31, 95), ale pouze pec odkrytá na Komenského ulici v Lošticích je nejlépe dochovaná. V daném případě je možné se blíže vyjádřit k jeji konstrukci a případným analogiím. 
16. století vyráběny proslulé loštické poháry. Kromě loštického zboží zde hrnčíři produkovali standardní keramiku a také komorové kachle. V roce 2019 získal autor článku od majitele domu čp. 103 kolekci nálezů, která podle jeho slov pochází z blíže nepopsané jámy u východní zdi výše uvedeného domu.

Vyzvednutou kolekci z jámy tvoří stolní a kuchyňská keramika ze závěru 15. až první poloviny 16. století, přechodný pozitiv a několik zlomků kadlubů určených k výrobě kachlů. Nalezené formy a přechodný pozitiv klademe spíše do druhé poloviny 15 . až prvních desetiletí 16. století. Dle sdělení majitele domu byla v minulosti kousek od jeho zahrady odkryta pec, která se nacházela $\mathrm{v}$ místech mezi jeho zahradou a silnicí $\mathrm{k}$ domu s pečovatelskou službou. Všechny tyto indicie naznačují, že na sklonku 15. až v první polovině 16. století někde v okolí domu mohla existovat hrnčířská dílna produkující běžnou i loštickou keramiku a také komorové kachle.

Článek touto cestou věnuji in memoriam svému učiteli PhDr. Vladimíru Gošovi, CSc. (* 8. zář́i 1942 $\dagger$ 15. ledna 2020).

\section{Literatura}

BLÁHA, J., 1983: K vypovídacím možnostem olomouckého archeologického materiálu 15. až 17. století, Historická Olomouc 4, 307-315.

- 1999: Keramické výrobky. In: Od gotiky k renesanci, výtvarná kultura Moravy a Slezska 1400-1550. III. díl. Olomoucko (Hlobil, I.-Perůtka, M., edd.), 587-591. Olomouc.

- 1999a: Svatomořická škola. In: Od gotiky k renesanci, výtvarná kultura Moravy a Slezska 1400-1550. III. díl. Olomoucko (Hlobil, I.-Perůtka, M., edd.), 616-626. Olomouc.

- 1999b: Kachle. In: Od gotiky k renesanci, výtvarná kultura Moravy a Slezska 1400-1550. III. díl. Olomoucko (Hlobil, I.-Perůtka, M., edd.), 596-603. Olomouc.

- 2005: K druhové skladbě masité stravy žáků Mořické školy a dominikánů u svatého Michala v Olomouci na přelomu 15. a 16. století, Střední Morava 25, 53-58.

BLÁHA, J.-GOŠ, V., 1999: Loštická keramika. In: Od gotiky k renesanci, výtvarná kultura Moravy a Slezska 1400-1550. III. díl. Olomoucko (Hlobil, I.-Perůtka, M., edd.), 592-595. Olomouc.

BLÁHA, J.-SEDLÁČKOVÁ, H., 1998: Slavnostní keramika - Festive ceramics. In: Sklo, slavnostní keramika a kachle. Archeologické výzkumy Památkového ústavu v Olomouci 1973-1996 (Sedláčková, H., ed.), 15-18. Olomouc.

DEHNEROVÁ, H.-HEJHAL, P., 2001: Loštice, ulice Hradská. NZ č. j. 2292/01, ulož. v archivu ARÚ Brno. - 2002: Loštice (okr. Šumperk), PV 43, 270.

DRECHSLER, A.-PAVLÍK, Č.-VITANOVSKÝ, M., 2008: Nevšední nález souboru keramických kadlubů, kachlů a nádob z Lipníku nad Bečvou, Sborník Státního okresního archivu Přerov 2008, 5-23.

DROBNÁ, Z., 1957: Loštické poháry. K otázce jejich datování a slohového zařazení, Český lid 44, 98-108.

ERNEÉ, M.-VITANOVSKÝ, M., 2003: Řezaná negativní dřevěná forma - první krok při výrobě čelní vyhř́vací stěny kamnového kachle? - Die geschnitzte Negativform aus Holz - der erste Schritt bei der Herstellung der reliefierten Blattkachel?, AR LV, 548-560.

FALTÝNEK, K., 2009: Adolf Lang, významný badatel z Loštic, Archeologie Moravy a Slezska IX, 259-274.

- 2012: Předběžná zpráva o výsledcích archeologických dohledů prováděných v Litovli v letech 2010 a 2011 a tak trochu o smyslu archeologie vůbec, Zajímavosti z Litovelska, Ročenka Muzejní společnosti Litovelska 2011, 77-110.

- 2015: Archeologické nálezy a lokality na katastru obce Žádlovice, Archeologie Moravy a Slezska XV, $21-47$.

GOŠ, V., 1978: Havelkovo muzeum v Lošticích. Katalog archeologické sbírky - Das Havelka-Museum in Loštice. Katalog der Archäologischen Sammlung, Zprávy Čs. společnosti archeologické při Čs. Akademii věd XX, č. 5, 134-165. 
- 1982: Hrnčířské pece severní Moravy, Zkoumání výrobních objektů a technologií archeologickými metodami 2, 25-32.

- 1983: Stř̌edověké hrnčiřství v Lošticích. (Pět let archeologických výzkumů města) - Mittelalterliche Töpferei in Loštice. Fünf Jahre archäologischer Untersuchungen, AH 8, 187-209.

- 1998: Hrnčíríi v Lošticích. In: Loštice, město a jeho obyvatelé (Goš, V., ed.), 59-61. Loštice.

- 2007: Loštice, město středověkých hrnčírů - Loštice - town of medieval potters. Opava.

- 2012: Z Loštic až na konec světa. Nové objevy severomoravské středověké keramiky v západní Evropě, VVM LXIV, 11-17.

GOŠ, V.-NOVÁK, J., 1976: Počátky výroby loštické keramiky - Die Anfänge der Lošticer Keramikproduktion, AR XXVIII, 399-404.

HAZLBAUER, Z.-HEIDENREICH, M.-LAMR, J., 2001: Stavební rekonstrukce pozdně gotických kachlových kamen v Muzeu Mohelnice, okr. Šumperk - Die Baurekonstruktion des spätgotischen Kachelofens im Museum in Mohelnice, Bez. Šumperk, AH 26, 387-402.

HLADIŠ, K., 1885: Loštické poháry, ČVSMO II, 184-186.

HLUBEK, L., 2015: Příspěvek k výrobě kamnářské keramiky v Lošticích - Contribution to production of stove ceramics at Loštice, Pravěk NŘ 23, 219-230.

- 2018: Loštice (okr. Šumperk), PV 59, č. 2, 252-254.

- 2019: Loštice (okr. Šumperk), PV 60, č. 2, 282-283.

- v tisku: Loštice (okr. Šumperk), PV 61, č. 2.

HOUDEK, V., 1891: Obchod a řemesla v Lošticích. In: Loštice rodiště Jana Havelky, 60-68. Olomouc.

JANDÍKOVÁ, Z., 1998: Loštice do poloviny 19. století. In: Loštice, město a jeho obyvatelé (Goš, V., ed.), 10-13. Loštice.

KUČA, K., 1998: Města a městečka v Čechách, na Moravě a ve Slezsku. III. díl. Kolín-Miro. Praha.

LANG, A., 1957: Z historie loštického hrnčírství, Severní Morava 1, 27-32.

- 1961: Loštické poháry. Přehled dosavadních výzkumů, Severní Morava 6, 54-63.

LANSFELD, H., 1976: Středověké a novověké kachle ze sbírek Heřmana Lansfelda. Strážnice.

LOSKOTOVÁ, I., 2011: Brněnské kamnové kachle období gotiky. Rkp. nepubl. disertační práce na FPF MU v Brně, vedoucí práce doc. PhDr. Rudolf Krajíc, CSc. Dostupné z: https://is.muni.cz/th/160571/ff_d/, cit. 18. 2. 2020.

MENOUŠKOVÁ, D.-VITANOVSKÝ, M., 2011: K technologii výroby středověkých kachlů. Dva neobvyklé kachlové reliéfy (přechodné pozitivy) s motivem sv. Jakuba Většího (?) z Prostějova a Šternberka - Zwei vorläufige Positivformen zur Herstellung von Kacheln mit dem Motiv des hl. Jakobus des Älteren (?) aus Prostějov und Šternberk. In: Archaeologia mediaevalis Moravica et Silesiana, 16-26. Brno.

NEKUDA, V.-REICHERTOVÁ, K., 1968: Středověká keramika v Čechách a na Moravě. Brno.

PAJER, J., 1983: Počátky novověké keramiky ve Strážnici. Strážnice.

PAVLÍK, Č., 2017: Velký obrazový atlas gotických kachlových reliéfů. Čechy, Morava, české Slezsko - Grosser Bildatlas gotischer Kachelreliefs. Böhmen, Mähren, Bömisch Schlesien. Praha.

PAVLÍK, Č.-VITANOVSKÝ, M., 2004: Encyklopedie kachlů v Čechách, na Moravě a ve Slezsku. Praha.

PREČANOVÁ, V., 1999: Odpadní jímka z domu čp. 7 na Dolním náměstí v Olomouci. Rkp. nepubl. bakalářské práce na FPF SlU v Opavě, vedoucí práce PhDr. Pavel Kouřil, CSc.

PROCHÁZKA, R., 2015: Mittelalterliche Töpferöfen in Mähren. In: Den Töpfern auf der Spur. Orte der Keramikherstellung im Licht der neuesten Forschung 46. Internationales Symposium Keramikforschung des Arbeitskreises für Keramikforschung und des Römisch-Germanischen Zentralmuseums Mainz vom 16. bis zum 20. September 2013 in Mayen (Grunwald, L., ed.), 215-224. Mainz.

ŠEFČÍK, E., 1984: Příspěvek k dějinám loštického hrnčířství (do třicetileté války), ČSIM B 33, 271-278.

ŠLÉZAR, P.-FALTÝNEK, K., 2019: Románský kostel sv. Prokopa v Lošticích. Příspěvek k počátkům moravské šlechty - The Romanesque church of st. Procopius in Loštice. Contribution to the beginnings of Moravian aristocracy, PV 60, č. 2, 161-199. 
ŠŤASTNÝ, M.-DUDEK, J.-GOŠ, V., 2018: Pocula loscicensia aperta. Tajemství výroby loštických pohárů odhaleno - Pocula loscicensia aperta. Loštic cups secrets revealed, Pravěk NŘ 26, 83-106.

TYMONOVÁ, M., 2014: Výroba kamnářské keramiky v českých zemích a dílna v Opavě - Production of stove ceramics in the Czech Lands and a workshop in Opava, AH 39, 155-175.

VITANOVSKÝ, M., 2008: Kadluby. In: Krása, která hřeje (Menoušková, D.- Měřínský, Z., edd.), 157-165. Uherské Hradiště.

VITANOVSKÝ, M.-MENOUŠKOVÁ, D., 2010: Kachlové formy z Prostějova - Kostelecké ulice. K technologickým a tvůrčím otázkám vzniku renesančních kachlových reliéfů - Stove tile moulds from Kostelecká St. in Prostějov (Central Moravia). On technological and creative issues relating to the rise of Renaissance stove tile reliefs, AR LXII, 680-695.

VITANOVSKÝ, M.-ŽEGKLITZ, J., 2011: Dva atypické kachlové reliéfy z produkce pražské hrnčířské dílny Adama Špačka (1531-1572) - Two atypical stove reliefs from the output of the Adam Špaček pottery workshop, Prague (1531-1572). In: Archaeologia mediaevalis Moravica et Silesiana, 27-34. Brno.

ZATLOUKAL, R., 2000: Archeologické doklady hrnčířství ve 13. až první polovině 16. století na Moravě, Archeologia technica 11, 60-74.

\section{Zusammenfassung}

\section{Neue Funde von zur Herstellung von Kacheln bestimmten Gießformen und einer provisorischen Positivform aus Loštice (Bezirk Šumperk)}

Die Stadt Loštice (Abb. 1) liegt im Westteil der Müglitzer Furche (Mohelnická brázda) in einer durchschnittlichen Höhe von $258 \mathrm{~m}$ über dem Meeresspiegel. In der archäologischen Literatur ist Loštice vor allem als mittelalterliches und frühneuzeitliches Töpferzentrum bekannt. Aufgrund von verschiedenen Erwähnungen in den schriftlichen Quellen und von im Intravillan der Stadt durchgeführten archäologischen Grabungen kann dort die Herstellung von sowohl gängiger, als auch der berühmten Loschtitzer Keramik als eindeutig nachgewiesen gelten. Demgegenüber liegen uns für die Herstellung von Ofenkeramik lediglich indirekte Indizien vor, bei denen es sich besonders um Funde von Gießformen handelt, zu denen uns die näheren Fundumstände unbekannt sind.

Im Jahr 2018 hat der Verfasser des vorliegenden Beitrags die Bekanntschaft des Eigentümers von Haus Nr. 103 in Loštice gemacht (Abb. 2; 6:1), der ihm eine Kollektion von Funden, einschließlich zweier defekter Exemplare Loschtitzer Töpferware übergab. Einige weitere Keramik- und Gießformfragmente erwarb der Verfasser im Jahr 2019 (Abb. 3; 4; 5:1-4). Bei dem Finder verblieb weiterhin das Fragment einer provisorischen Positivform (Abb. 5:5). All diese Funde wurden vom Hauseigentümer aus einer Grube an der Ostwand des Hauses gehoben. Die Keramik kann ebenso wie die Gießformen in die Zeit Ende 15. bis erste Hälfte 16. Jahrhundert gelegt werden. Man kann einräumen, dass der Töpfer misslungene oder defekte Erzeugnisse in der an der Ostwand des Hauses gelegenen Grube entsorgt hat. Eine weitere wichtige Information über eine mögliche Töpferwerkstatt in der Umgebung des Hauses stützte der Besitzer der Immobilie mit der Mitteilung über die Entdeckung eines Ofens zwischen der heutigen, zu dem Haus, in dem heute ein Pflegedienst untergebracht ist, führenden Straße und dessen Garten (Abb. 6:6). Überdies registrieren wir in der Umbegung von Haus Nr. 103 mehrere Stellen (Abb. 6:2-5), welche die Lokalisierung von Töpferwerkstätten in diesem Teil der Stadt andeuten. Es scheint höchstwahrscheinlich zu sein, dass irgendwann gegen Ende des 15. und in der ersten Hälfte des 16. Jahrhunderts in Loštice irgendwo in der Umgebung von Haus Nr. 103 eine Töpferwerkstatt existierte, in der sowohl gängige und speziell Loschtitzer Keramik, als auch Blattkacheln hergestellt worden sind. 
Der vorliegende Artikel wird auf diesem Wege in memoriam meinem Lehrer, Herrn PhDr. Vladimír Goš, CSc., gewidmet $(* 8$. September $1942-\dagger 15$. Januar 2020).

Mgr. Lukáš Hlubek, Vlastivědné muzeum v Olomouci, nám. Republiky 5, 77173 Olomouc, Česká republika, hlubek@vmo.cz 
